\title{
Proximate and Mineral Composition of Locally Sourced Suya Spices Sold In Agege Area of Lagos State
}

\author{
T.O. Akinola, O.O. Fatunmibi, O.T. Alake, A.E. Asagbra, Onawola O.O.
}

\begin{abstract}
Suya spices are seasonings added to suya (Barbeque meat) and are becoming famous as compliments to meals such as fries and soups. Suya spice is consumed majorly in the northern part of Nigeria and by a few southerners. This study is aimed at analyzing the proximate and mineral compositions of suya spice obtained within Agege metropolis with respect to ingredients, processing, handling and storage respectively. Suya spice samples were obtained from Oko oba, Mangoro, Abule egba, Oniwaya and Pen cinema areas within Agege and from Ikeja as the control sample. The proximate analyses of the suya spices were determined by adopting the methods as described by the Association of Official Analytical Chemists (AOAC) and Pearson's Chemical Analysis of Food. Results of proximate analyses showed significant differences in most of the parameters. Ash content was observed to be highest in Oniwaya sample (4.65 \pm 0.42$)$, crude fibre was highest in the Ikeja sample (14.91 \pm 0.02$)$, fat content was highest in Abule egba sample (14.04 \pm 0.05$)$, protein content was highest in Pen cinema sample $(10.29 \pm 0.09)$, carbohydrate was highest in Mangoro sample and Energy value was highest in mangoro sample $(56.34 \pm 0.73)$ respectively, while moisture content was least in Pen cinema sample $(6.09 \pm 0.06)$. Results of the mineral composition revealed sodium content to be highest in the Ikeja sample (13.75 \pm 0.02$)$, potassium was highest in Oko oba sample (56.70 \pm 0.01 ), iron was highest in Mangoro sample 1.58 \pm 0.01 , calcium was highest in Abule egba $(21.46 \pm 0.26)$ and Oko oba samples $(\mathbf{2 1 . 4 6} \pm 0.01)$ respectively,while magnesium $(9.59 \pm 0.012)$ and copper $(1.59 \pm 0.01)$ were observed to be highest both in Abule egba sample respectively. The lead content was reported to be less than $0.1 \mathrm{ppm}$ in all samples. As such, suya spices which are made from natural ingredients and possessing high nutritive values may be recommended as a natural flavour enhancer in foods and sauces.
\end{abstract}

Index Terms - Ginger, Mineral, Proximate, Suya Spice.

\section{INTRODUCTION}

Highlight Spices are used in cooking to add flavour and aroma to foods. Commonly used spices are thyme, curry, nutmeg, sweet basil and pepper. Suya spices are Nigerian native spices usually a blend of various spices, used on roasted meat (barbecued meat) to provide it with a distinctive wanted taste and flavour. It is the special blend of peppers and

Titilope .O. Akinola, Analytical Services Division, Federal Institute of Industrial Research, Oshodi, Nigeria

Omolara .O. Fatunmibi, Analytical Services Division, Federal Institute of Industrial Research, Oshodi, Nigeria

Oluwaranti .T. Alake, Analytical Services Division, Federal Institute of Industrial Research, Oshodi, Nigeria

Agnes .E. Asagbra, Analytical Services Division, Federal Institute of Industrial Research, Oshodi, Nigeria

Oluwabukola .O. Onawola, Biotechnology Department, Federal Institute of Industrial Research, Oshodi spices and has its origin from the Hausas in the Northern Nigeria [1]. It was traditionally used as a dry rub on skewered grilled meat sold as street food. It is to Nigeria what Berbere is to Ethiopia, Ras el Hanout to Morocco, Garam masala is to parts of India. The spice consists of grinded pepper (Capsicum sp.), Xylopiaaethiopica, Piper guineense and Monodoramyristica [1] and [2]. These spices aid in giving palatable flavour and aroma to suya.

Because suya spices are often sold alongside suya meat, whose consumption poses a higher risk on health, it is important to analyze the proximate and mineral composition of suya spices separately to promote its commercialization and consumption without having to eat suya. Proximate and mineral analysis of food plays an important role in evaluating their nutritional significance and how beneficial they are to health and since suya spices are made from various condiments and spices such as peanut, ginger, onion, chilli pepper, paprika and salt, it is important to establish its nutritional composition to encourage commercialization thereby making it readily available to consumers in more hygienic conditions. From our study, we have been able to establish that suya spices are packed with highly beneficial nutritional and mineral compositions and can therefore be utilized without having to eat suya.

\section{MATERIALS AND METHOD}

\section{A. Materials}

Suya spices were purchased from five suya vendors at Oko oba, Mangoro, Abule egba, Oniwaya and Pen cinema areas of Agege, Lagos State, Nigeria. A branded suya spice, regarded as the control sample was purchased from Shoprite, Ikeja, Lagos state.

All reagents and chemicals used were of Analytical grade. B. Methods

Proximate analysis

This was carried out as described by [11] and [12]

Moisture Content

Moisture content was determined by adopting the vacuum oven drying methods using the MermettTM vacuum oven at $70^{\circ} \mathrm{C} \pm 2^{\circ} \mathrm{C} .3 \mathrm{~g}$ each of the samples were weighed into dry and previously weighed petri dishes. These were dried to constant weight. Moisture content was calculated as amount of water lost as a percentage of the initial weight of sample.

\section{Ash Content}

Ash was determined using the CarboliteTM Muffle Furnace at $450^{\circ} \mathrm{C} \pm 5^{\circ} \mathrm{C}$ for 3 hours (h). $2 \mathrm{~g}$ each of the samples were weighed into correspondingly labelled porcelain flat 
bottom crucibles and placed at the entrance of the open furnace to expel fumes. They were then ashed for 30 minutes (min) at $450^{\circ} \mathrm{C} \pm 5^{\circ} \mathrm{C}$. Several drops of distilled water were added after which the samples were evaporated to dryness and returned to the furnace for another $30 \mathrm{~min}$. Samples were thereafter cooled in the desiccator and weighed. Ash content was calculated as amount of substance retained as a percentage of the initial weight of sample.

\section{Total Fat Content}

Total Fat was determined using the soxhlet extraction method using FOSSTM Soxhtec 2050 equipment. $3 \mathrm{~g}$ of each sample was weighed into a cellulose thimble of $33 \times 80 \mathrm{~mm}$ dimension and attached to the magnetic holder of the equipment to which were attached correspondingly labelled aluminium cups containing $70 \mathrm{mls}$ of petroleum ether. They were fitted onto the heating mantle with an operating temperature of $100^{\circ} \mathrm{C} \pm 2^{\circ} \mathrm{C}$ for $80 \mathrm{~min}$ for continuous extraction. Thereafter the aluminium cups are placed on a steam bath for $30 \mathrm{~min}$ to evaporate the ether and later dried at $100^{\circ} \mathrm{C} \pm 2^{\circ} \mathrm{C}$ in the oven, cooled and weighed until a constant weight was achieved. Fat content was calculated as amount of substance retained as a percentage of the initial weight of sample.

\section{E. Crude Fibre Content}

Crude Fibre was determined using the FOSSTM Fibretec hot and cold extraction units. To $1 \mathrm{~g}$ each of celite in labelled sintered glass crucibles were added $1 \mathrm{~g}$ each of the samples. To theses were added $1.25(\% \mathrm{v} / \mathrm{v})$ sulphuric acid and 1.20 $(\% \mathrm{w} / \mathrm{v})$ sodium hydroxide and thereafter transferred into the columns for sample digestion. To each digestion tubes were added 3 drops of octan-1-ol. Samples were washed with distilled water and drained and thereafter transferred to cold extraction unit whilst eliminating traces of fat using acetone. Samples were dried in the oven at $130^{\circ} \mathrm{C} \pm 2^{\circ} \mathrm{C}$ for $2 \mathrm{~h}$. Samples were cooled and weighed and returned to the furnace at $525^{\circ} \mathrm{C} \pm 15^{\circ} \mathrm{C}$ for about $3 \mathrm{~h}$ until constant weight was achieved. A blank determination containing no sample was carried out to balance errors. Crude fibre content was calculated as amount of substance retained as a percentage of

Table 1: Proximate composition of suya spices obtained from Oko oba, Mangoro, Abule egba, Oniwaya, Pen cinema and Ikeja as the control sample.

\begin{tabular}{|c|c|c|c|}
\hline Parameter & $\begin{array}{r}\text { Suya spice s } \\
\text { points }\end{array}$ & & \\
\hline$(\% \mathrm{w} / \mathrm{w})$ & $\begin{array}{l}\text { Ikeja } \\
\text { (Control) }\end{array}$ & & Oko oba \\
\hline Moisture & $6.91 \pm 0.04^{c}$ & b & $6.33 \pm 0.18^{a}$, \\
\hline Ash & $4.55 \pm 0.14^{c}$ & & $4.54 \pm 0.50^{c}$ \\
\hline Crude fibre & $14.91 \pm 0.02^{d}$ & d & $14.76 \pm 0.29$ \\
\hline Fat & $12.75 \pm 0.10^{c}$ & $\mathbf{c}$ & $12.54 \pm 0.08$ \\
\hline Protein & $10.19 \pm 0.01^{c, d}$ & $c, d$ & $10.20 \pm 0.07$ \\
\hline Carbohydrate & $50.60 \pm 0.11^{\mathrm{a}}$ & a & $51.48 \pm 0.83$ \\
\hline $\begin{array}{l}\text { Energy } \\
\text { cal/100g) }\end{array}$ & $358.16 \pm 0.30^{b}$ & $5^{\mathrm{b}}$ & $361.93 \pm 2.7$ \\
\hline
\end{tabular}

Results represent Means \pm SEM. Any two means not followed by the same letter are significantly different. the initial weight of sample.

\section{F. Protein Content}

Protein was determined using FOSSTM digester and distillation units followed by titrimetry. Into labelled digestion tubes were weighed $2 \mathrm{~g}$ each of samples and to these were added $20 \mathrm{ml}$ of sulphuric acid and two kjeltabs as catalysts. These were digested at $430^{\circ} \mathrm{C} \pm 5^{\circ} \mathrm{C}$ for $1 \mathrm{~h}$. The tubes were then transferred into distillation columns and further digested with $10 \mathrm{M} \mathrm{NaOH}$ and the distilled ammonia is collected into the green boric acid solution which changed to pink after about 6 minutes of distillation. The boric acid solution was then titrated against $0.1 \mathrm{M} \mathrm{HCl}$ to a bluish-green endpoint.

$\%$ Nitrogen $=$ Titre value $\times$ Conc. Of Acid $\times 14.007 \times 100$

Weight of sample

$\%$ Protein $=\%$ Nitrogen $\times 6.25$ 1000

Carbohydrate content was determined according to the method of [3] as the difference in the sum total of all proximate parameters from 100.

Energy Value was determined by estimation as the sum of protein and carbohydrate values multiplied by 4 and fat content by 9 as described by [3].

\section{G. Mineral Analysis}

Mineral composition was determined in accordance with AOAC, (2010) using Shimadzu ${ }^{\text {TM }}$ AA-7000 series Atomic Absorption Spectrophotometer (AAS). This was carried out after dry ashing and acid digestion of samples.

H. Statistical data processing

All analyses were carried out in triplicates and data was analyzed by the One-way Analysis of Variance (ANOVA) using SPSS (version 23). [4]. Results were expressed as Mean \pm standard error of mean. Significant differences among the treatment means were evaluated using the Tukey HSD and the new Duncan multiple range test at $\mathrm{p} \leq 0.05$.

\section{RESULTS}

\begin{tabular}{|c|c|c|c|}
\hline Mangoro & $\begin{array}{l}\text { Abule } \\
\text { egba }\end{array}$ & Oniwaya & Pen cinema \\
\hline $7.04 \pm 0.06^{c}$ & $3^{\mathrm{b}} 6.52 \pm 0.0$ & $7.16 \pm 0.03^{c}$ & $6.09 \pm 0.06^{a}$ \\
\hline $3.86 \pm 0.60^{\mathrm{a}}$ & $4^{b} 4.13 \pm 0.0$ & $3.38 \pm 0.26^{a}$ & $4.65 \pm 0.42^{c}$ \\
\hline $11.46 \pm 0.17$ & $5^{\mathrm{c}}$ & $14.74 \pm 0.08^{d}$ & a $10.17 \pm 0.05$ \\
\hline $11.15 \pm 0.13$ & $5^{\mathrm{d}}$ & $10.66 \pm 0.14^{\mathrm{a}}$ & d $13.66 \pm 0.06$ \\
\hline $9.96 \pm 0.07^{c}$ & $3^{\mathrm{a}} 8.25 \pm 0.0$ & $9.43 \pm 0.02^{b}$ & d $10.29 \pm 0.09$ \\
\hline $56.34 \pm 0.73$ & $13^{\mathrm{b}}$ & $54.46 \pm 0.36^{b}$ & b $55.06 \pm 0.44$ \\
\hline $368.89 \pm 2.5$ & $1^{377.76 \pm 0}$ & $352.48 \pm 0.34^{\mathrm{a}}$ & $7^{\mathrm{e}} 384.66 \pm 0.8$ \\
\hline
\end{tabular}




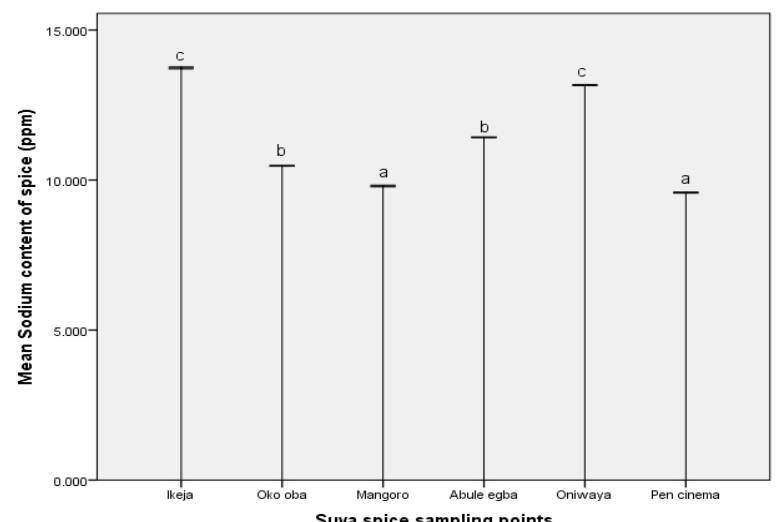

Fig. 1: Sodium content of suya spices obtained from Oko oba, Mangoro, Abule egba, Oniwaya, Pen cinema and Ikeja as the control sample respectively. Any two means not followed by the same letter are significantly different from each other.

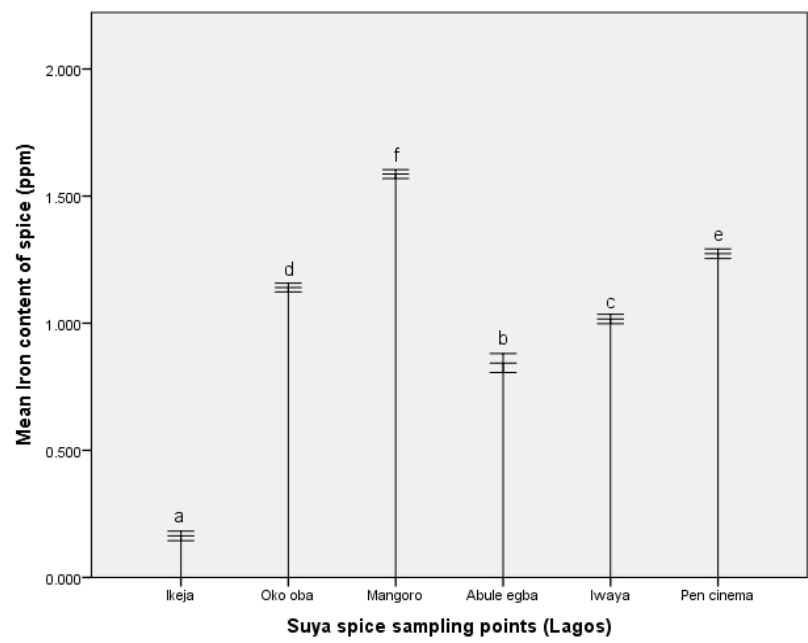

Fig 2: Iron content of suya spices obtained from Oko oba, Mangoro, Abule egba, Oniwaya, Pen cinema and Ikeja as the control sample respectively. Any two means not followed by the same letter are significantly different from each other.

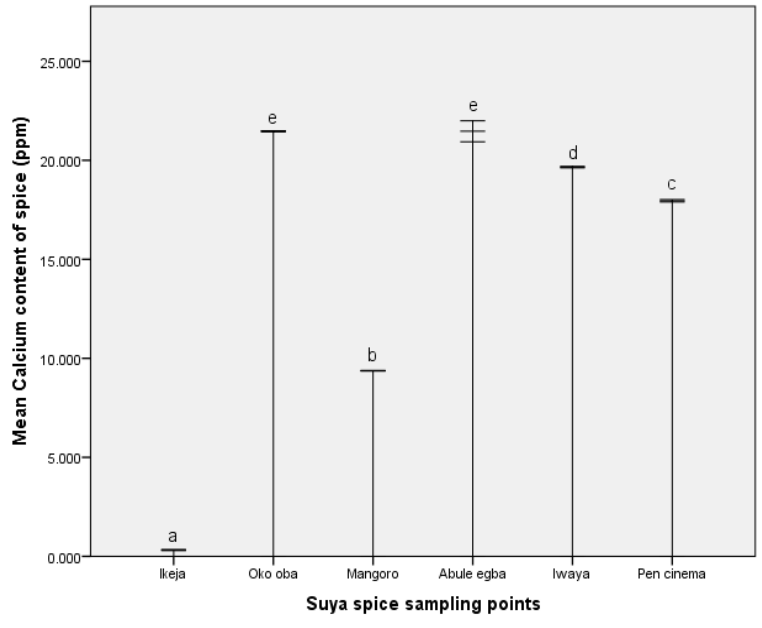

Fig 3: Calcium content of suya spices obtained from Oko oba, Mangoro, Abule egba, Oniwaya, Pen cinema and Ikeja as the control sample respectively. Any two means not followed by the same letter are significantly different from each other.

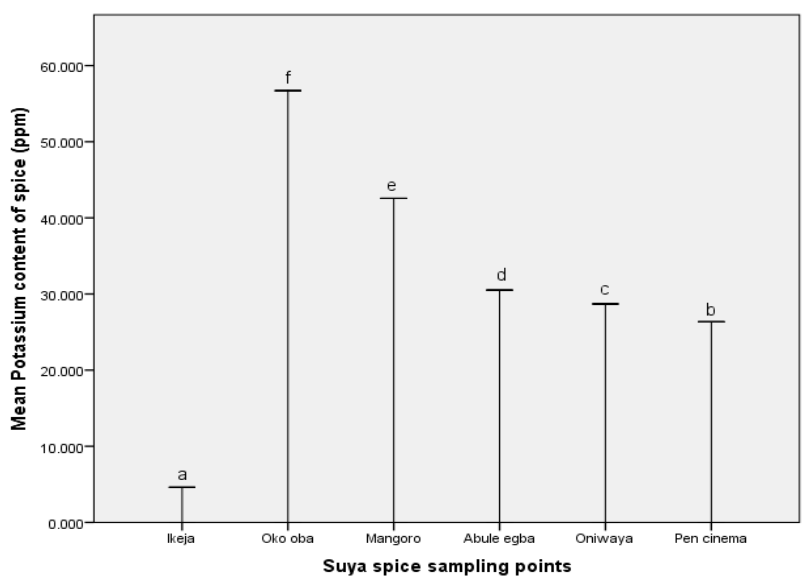

Fig 4: Potassium content of suya spices obtained from Oko oba, Mangoro, Abule egba, Oniwaya, Pen cinema and Ikeja as the control sample respectively. Any two means not followed by the same letter are significantly different from each other.

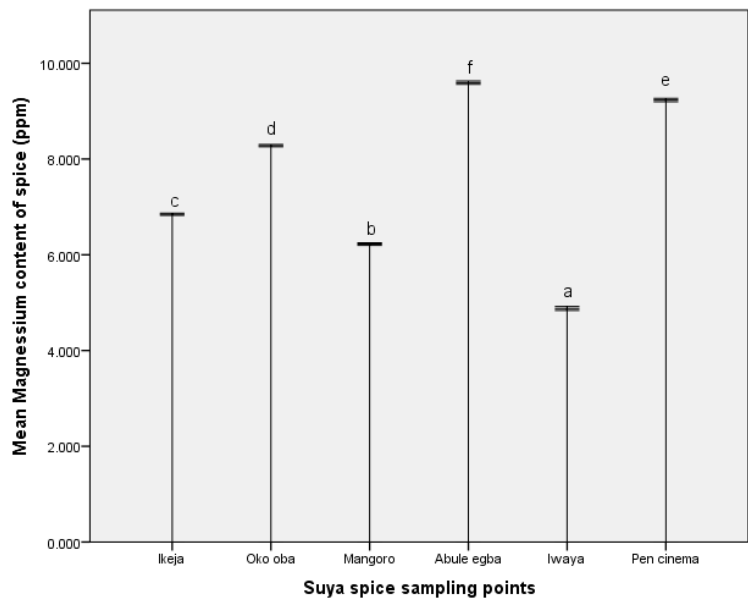

Fig 5: Magnesium content of suya spices obtained from Oko oba, Mangoro, Abule egba, Oniwaya, Pen cinema and Ikeja as the control sample respectively. Any two means not followed by the same letter are significantly different from each other.

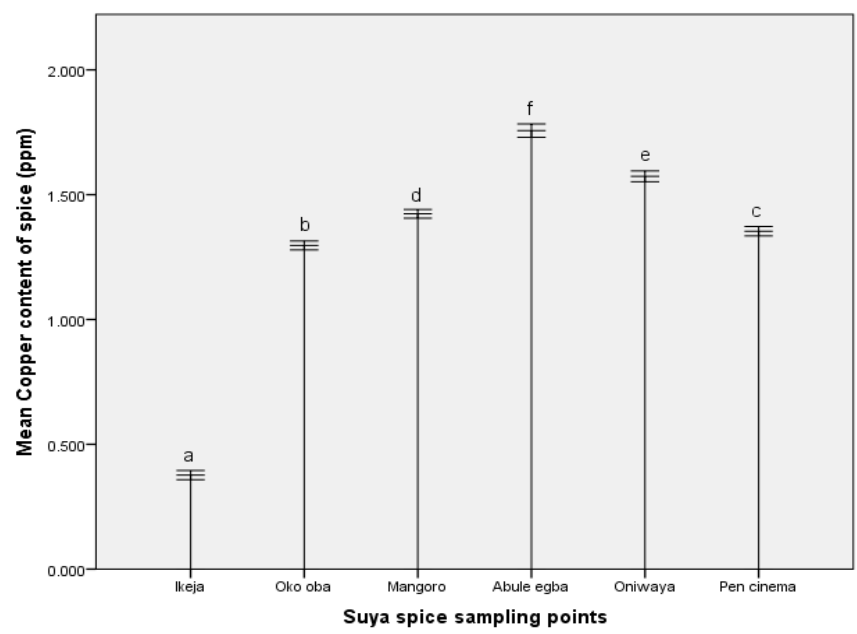

Fig 6: Copper content of suya spices obtained from Oko oba, Mangoro, Abule egba, Oniwaya, Pen cinema and Ikeja as the control sample respectively. Any two means not followed by the same letter are significantly different from each other. 
Proximate and Mineral Composition of Locally Sourced Suya Spices Sold In Agege Area of Lagos State

Table 2: Heavy metal (Lead) content of suya spice obtained from Oko Oba, Mangoro, Abule Egba, Oniwaya, Pen Cinema and

Ikeja as the control sample.

\begin{tabular}{|l|c|c|c|c|c|c|}
\hline Metal & \multicolumn{7}{|c|}{ Suya spice sampling points } \\
\hline & Ikeja(Control) & Okooba & Mangoro & Abuleegba & Oniwaya & $\begin{array}{l}\text { Pencine } \\
\text { ma }\end{array}$ \\
\hline $\begin{array}{l}\text { Lead } \\
(\mathbf{p p m})\end{array}$ & $<0.1$ & $<0.1$ & $<0.1$ & $<0.1$ & $<0.1$ & $<0.1$ \\
\hline
\end{tabular}

*ppm - parts per million

\section{DISCUSSION}

Low moisture contents below $10 \%$ with significant differences were observed for all brands of suya spices (Table 1). The differences in moisture levels may be due to the moisture levels of the other components of the spice or due to improper spice packaging or storage of spice in humid environments. However, the low moisture levels may suggest that they might be less prone to microbial attack. [5] and [6] reported that levels of moisture content give meaning to the presence of microbes in foods. The moisture content of any food is an index of its water activity and is used as a measure of the stability and susceptibility to microbial contamination [13]. Hence, the low moisture content may permit the suya spice to be stored for a long period with minimal microbial contamination. Low moisture content can therefore enhance the stability of the spices after processing.

Ash constitutes the inorganic component of food and this provides us with an estimate of the mineral constituents of the food. The ash content is often regarded as an index of mineral content in biological mass [14]. The ash content of the spices were observed to be significantly higher in three of the brands, including the branded sample (Control). These differences may probably be due to the difference in the origin and varieties of samples [6]. Also the storage of food samples may possibly affect the ash contents as improperly stored samples are prone to microbial attacks and contamination with foreign particles which might contribute to a higher ash value.

Fat content is significantly higher in two of the samples and the difference in fat contents of the spices might be due to the amount of fat contained in the type/source of spices used. Protein sources with higher fat contents, and such as in the full fat state will introduce higher fat levels. The fat content of the foods may constitute saturated, trans, monounsaturated and polyunsaturated fats [7]. High fat content in suya spice is however undesirable as this may pose problems of rancidity, leading to off-flavours and hence a reduction in its shelf life. In addition, a protein source supplying high fat content may be low in crude protein content (Table 1).

Protein are required for body building, renewal of body cells and a host of other physiologic functions, as such, its relevance cannot be over-emphasized. Suya Spice with high protein content is therefore most desirable. Significant protein values were observed in some of the samples, including the control sample with high fat contents (Table 1). This may be due to higher inclusion amounts of the protein source which incidentally may also double as the fat source in the spice. However, the protein content of the suya spices from the different sampling points were observed to be higher than the $5.9 \%$ protein value for suya spices obtained at Rumuokoro area (RS1) of Port Harcourt reported by [8] The high difference in value with reports of [8] may be due to the use of a different source of protein, presumably one with higher protein contents than was employed in Port Harcourt. Crude fibre is a diet component that aids bowel movement and it is relevant in digestion as this promotes better absorption of food into the body. All samples were observed to high in crude fibre content with significant differences (Table 1). Three of the samples, including the control sample were significantly richer in crude fibre than the others. This may be due to a higher inclusion level of some of the components of the spices which possess higher fibre values by different local entrepreneurs. These include ginger, turmeric, cinnamon and cloves and these could be more instrumental to the significant higher values of crude fibres recorded in some of the samples.

The carbohydrate contents observed in the study were high taking as high as $50 \%$ of the total component (Table 1 ). However, significant differences though slight were observed in all samples with higher contents in three of the samples. Energy values observed in the study were also high with significant differences among the samples. The high energy values are expected and theses might have been contributed majorly by the high carbohydrate level and possibly by the fat too.

From Table II and Graph II, it was noted that the mineral composition of the all the suya spices are rich in minerals. This is because condiments and spices are known be good sources of vitamins and minerals.

The mineral composition of the spices from the different sampling points all revealed high levels of the macronutrient and low levels of the micronutrient with significant differences in their amounts. Significantly higher values obtained for sodium in three of the samples including the control might be due to high inclusion level of food grade sodium chloride (supplied as common salt) in the spice (Fig.1). Edible salt is usually added to foods as a seasoning and for preservation purpose a high inclusion level will result into high levels of sodium. Sodium is the principal cation in extracellular fluids. It regulates plasma volume and acid-base balance, involved in the maintenance of osmotic pressure of the body fluids, preserves normal irritability of muscles and cell permeability, activates nerve and muscle function. [9]. The sodium content of all the spices under study were within the range of the sodium content in table salts $(38,000 \mathrm{mg} / 100 \mathrm{~g})$ and bouillon cubes $(20,000 \mathrm{mg} / 100 \mathrm{~g})$ as stated by [15] . 
Iron functions as haemoglobin in the transport of oxygen. [9] throughout the body. Iron contents observed were low with significantly higher values in all samples above the control brand (Fig. 2). The difference may arise due to levels of iron in some of the components of the spices. Iron is required as a micronutrient and its low quantity in suya spices under study may be considered beneficial to health.

Calcium functions as a constituent of bones and teeth, regulation of nerve and muscle function. [9]. The calcium contents are as presented in Fig. 3. Significantly higher values observed in all samples above that in the control brand may be due to use of components with higher calcium contents. Oko Oba has the highest calcium concentration with a value of $21.46 \mathrm{ppm}$ which is slightly higher than that of suya spices obtained at Trans-Amadi (5) area of Port Harcourt with a value of $21.20 \mathrm{ppm}$ as reported by [8]

Significantly higher values obtained for potassium in all samples above the control brand might also be due to higher inclusion levels of some of the components, such as turmeric which is a component of suya spices in some areas. Potassium is the principal cation in intracellular fluid and functions in acid-base balance, regulation of osmotic pressure, conduction of nerve impulse, muscle contraction particularly the cardiac muscle, cell membrane function and $\mathrm{Na}+\mathrm{K}+$-ATPase. [9]. This makes it beneficial to health.

The health status of the digestive system and the kidneys significantly influence magnesium status. Magnesium is absorbed in the intestines and then transported through the blood to cells and tissues. [9]. It is a macronutrient and its value in suya spice may not be alarming if it falls within dietary value. Significantly higher values were obtained for all samples except one (Fig.5). The high values however contradict the finding of [8] who reported lower concentrations of suya spices obtained from Trans Amadi area (1) in Port Harcourt. This disparity could be attributed to the use of different components with varying mineral contents as suya spice ingredients.

Significantly higher values obtained for copper levels in all samples above the control brand (Fig. 6) might also be due to higher inclusion levels of some of the spice components with high copper values. However, copper is required as a micronutrient and the low levels observed may be beneficial to health.

The observed very low lead content (a heavy metal) falls within the permissible lead limits as stated in [10]. This suggests a safe level in the consumption of suya spice.

The proximate and mineral contents of suya spices obtained from various locations within the Agege Area of Lagos State showed similarities with significant differences in values. This could in general be attributed to individual choice of ingredients, manufacturing preferences and conditions of manufacture as well as storage conditions. [8] reported that some of the similarities may be attributed to a common background to which the producers belong, such as from the same ethnic group (Hausa of Northern Nigeria). The disparities may be due to the choice and little difference in the quantity of the various ingredients used in production. The variations in the mineral contents of the suya spices may also arise as a result of choice of ingredients used and quality and quantity preferences. However, processing, packaging and storage processes may also play a role in determining the elemental composition.

\section{CONCLUSION}

Suya spices are made from natural spices and seasonings and have high nutritive values. This is in great contrast to regular stock cubes which contains synthetic flavour enhancers such as monosodium glutamate, high amounts of salt, sugar, disodium inosinate etc. and which may pose a threat to health especially in hypertensive individuals. Suya spice may serve as a seasoning in soups and other delicacies, for flavour enhancement in cooking and health benefits.

\section{CONFLICT OF INTEREST}

The authors declare that there is no conflict of interest during the course of this study.

\section{ACKNOWLEDGMENT}

The authors acknowledge the technical assistances of $\mathrm{Mr}$. G.O. Asieba and Mr. B.J. Awogbemi of the Analytical Services Division, Federal Institute of Industrial Research, Oshodi, Lagos, Nigeria.

\section{REFERENCES}

[1] S.G., Jonathan M.A., Adeniyi and M.D. Asemoloye (2010), fungal biodeterioration, aflatoxin contamination, and nutrient value of "suya spices", Scientifica, vol. 2010, Article ID 4602036, pp 6.

[2] M.Y. Nwaiwu and E.O. Imo (1999), Control of food borne fungi by essential oil from local spices in Nigeria, Acta Phytopathologica et Entomologica Hungarica, 34:1-3.

[3] A. Dagem., D. Gulelat., A. Kebede, B.D. Beruk and G. Dereje. (2010), Proximate, mineral composition and sensory acceptability of home made noodles from stinging nettle (urticasimensis) leaves and wheat flour blends, International Journal of Food Science and Nutrition Engineering, 6(3): 55-61.

[4] Statistical Package for the Social Sciences (2015). Version 23.

[5] L.M. Prescott, J.P. Harley and D.A. Klein (2002), Microbiology, 5th Edition, McGraw-Hill. London. pp 963-971.

[6] A.B. Armand., Y.N. Nicolas., S.F. Harquin., S. Joel, M. Didier, M.F.M. Carl. (2012). Proximate composition, mineral and vitamin content of some wild plants used as spices in Cameroon. Food and Nutrition Sciences, (3), 423-432.

[7] McKinley Health Center, University of Illinois at Urbanachampaign. 'Macronutrients: the importance of Carbohydrate, Protein and Fat', Retrieved 20 September 2014.

[8] Ngozi NmaOdu, Akwasiam Best, Iheanyi Omezuruike Okonko (2017). proximate and mineral composition of suya spices sold in Port Harcourt, Nigeria, Scientific and Academic Publishing, Food and Public Health, p-ISSN: 2162-9412e-ISSN: 216284402017; 7(2): 35-39

[9] K.O. Soetan, C.O. Olaiya and O.E. Oyewole (2010). 'The importance of mineral elements for humans, domestic animals and plants: A review.' African Journal of Food Science Vol. 4(5), pp. 200-222

[10] Codex Alimentarius International Food Standards. (1995). 'General standard for contaminants and toxins in food and feeds' (Codex STAN 193-1995)

[11] AOAC (Association of Official Analytical Chemists), (2010). Official methods of Analysis of AOAC International, $18^{\text {th }}$ edition, Washington DC, USA.

[12] E. Harold, S.K Ronald. and Ronald Sawyer (1981), Pearson's Chemical Analysis of Foods, $8^{\text {th }}$ Edition, Churchill Livingstone, 1981, ISBN 044302149X, 9780443021497

[13] C.A. Edem and I.D. Miranda (2011). Chemical Evaluation of Proximate Composition, Ascorbic acid and Anti-nutrients Content of African star apple (Chrysophyllum africanum) Fruit, IJRRAS9 (1): 146-19. 
[14] G.S. Effiong and I. F. Udo, (2010). Nutritive Values ofFour Indigenous Wild Fruits In Southeastern Nigeria, Electronic Journal Of Environmental, Agricultural And Food Chemistry, 9(7): 1168-1176.

[15] WHO, (2012). Guideline: Sodium intake for adults and children. Geneva, World Health Organization (WHO), pp. 26

Titilope .O. Akinola is an food and non food analyst and a research officer at the Analytical Services division of the Federal Institute of Industrial Research, Oshodi., Lagos, Nigeria. She is a graduate of pure and applied chemistry from Federal University of Agriculture, Abeokuta, Ogun State with a master's degree in analytical chemistry in view. She holds a certification in Health, Safety, Security and Environment (HSSE) validated by ShadowSEC International, UK and is a team member of the ISO 17025:2005 accreditation team for the department of Production, Analytical and Laboratory Management (PALM )of FIIRO. She holds membership positions in Chemical Society of Nigeria (CSN) as well as Nigerian Institute of Food Science and Technology (NIFST) and is an applicant of the Irish Research Council Grant. Titilope has three (3) journal publications and one conference proceeding to her credit. She loves reading, researching and watching movies in her spare time.

Omolara .O. Fatunmibi is an assistant quality manager and analyst in the food and non food section of the analytical services division, Federal Institute of Industrial Research, Oshodi., Lagos, Nigeria. She holds a B.Tech in Pure and Applied Chemistry from Ladoke Akintola University, Ogbomosho, Oyo State, Nigeria. She also obtained a postgraduate diploma in Education from Usman Danfodio University, Sokoto State, Nigera. She is a member of Institute of Chartered Chemists of Nigeria (ICCON) and has attended a training on Laboratory Quality Management Systems towards ISO/IEC 17025:2005 accreditation. She has one (1) publication on the "

phytochemical composition and in vitro antioxidant activity of golden melon ( Cucumis melo L.) seeds for functional food application". She enjoys reading in her spare time.

Oluwaranti .T. Alake is a food and non food analyst and a research officer at the analytical services division of the Federal Institute of Industrial Research, Oshodi., Lagos, Nigeria. She holds a Bachelor of Science in Chemistry from the University of Lagos, Nigeria and a Master's degree in Pharmaceutical Chemistry from the University of Ibadan, Oyo State, Nigeria. She holds a certification in Data Analysis and Information Management and also has a $\mathrm{PhD}$ in Analytical Chemistry in view. She loves reading and travelling.

Dr Agnes Yemisi Asagbra is a Microbiologist and a Research Director in the Department of Production, Analytical and Laboratory Management (PALM) of the Federal Institute of Industrial Research Oshodi (FIIRO), Lagos, Nigeria. She obtained her Bachelor of Science degree with honours in biology from the University of Lagos in 1983, a Master of Science degree in the food and industrial Microbiology in the year 1987 from the University of Benin, Nigeria and a Doctorate in the food and industrial Microbiology from the University of Ibadan. She holds professional certificates in Quality management systems (ISO 9001: 2015) and Food Safety Management System (ISO22000: 2017). An ISO 9001: 2015 and ISO22000: 2017 auditor. She has successfully upgraded the local technology for the production of Kunun-zaki (a fermented beverage) and ogiri (condiment) by the application of the concept of Hazard Analysis and Critical Control Points (HACCP).

She is a trainer of FIIRO technology trainees and SME's on HACCP. She has worked on alcoholic, antibiotic and solid- state fermentations to mention a few. She holds membership positions in the Nigerian society for Microbiology, Association of industrial

Microbiologists of Nigeria, Nigerian Institute Of Food Science And Technology (a Fellow) and the Institute of Public Analysts of Nigeria.

She has twenty-six (26) peer reviewed journal publications in both local and international journals and twenty (20) conference proceedings to her credit. She loves reading and travelling.

Ms Oluwabukola Oluwatoyin Onawola is a Biochemist and a Principal Research Officer in the Department of Biotechnology of the Federal Institute of Industrial Research Oshodi (FIIRO), Lagos, Nigeria. She obtained her Bachelor of Science degree with honours in biochemistry from the University of Ilorin in 1992 and a Master of Science degree in the same field in the year 2010 from the University of Lagos, Nigeria respectively. She is currently on her PhD program at the University of Lagos. She holds professional certificates in Master of Business Administration from the University of Ilorin and in Food Safety Management Systems (Management of Microbiological Hazards in Foods) which she obtained from the Wageningen University of Research, The Netherlands in collaboration with Bells University of Technology, Ota 2013. She has successfully upgraded the local technology for the production of ogiri (a food condiment) by the application of the concept of Hazard Analysis and Critical Control Points. (2008). She is also an awardee of the grant given by West African Agricultural Project (WAAP) NCRP-Product Development Proposals for the project "Production of high quality phytase from local substrates for application in animal feed" (2010) amongst others. She holds membership positions in the Nigerian society of biochemistry and molecular biology, Nigerian institute of food science and technology and the Association of industrial microbiologists of Nigeria respectively. She has eight (8) peer reviewed journal publications in both local and international journals and five conference proceedings to her credit. Ms Onawola has interests in reading, organizing events, animal husbandry and tailoring. 